\title{
Erratum to: Synthesis and fabrication of Mg-doped ZnO-based dye-sensitized solar cells
}

\author{
I. Polat · S. Yllmaz $\cdot$ E. Bacaksız $\cdot$ Y. Atasoy \\ M. Tomakin
}

Published online: 18 July 2014

(c) Springer Science+Business Media New York 2014

Erratum to: J Mater Sci: Mater Electron (2014)

\section{5:3173-3178}

DOI 10.1007/s10854-014-2000-5

Unfortunately, the word 'sensitized' was wrongly stated as 'synthesized' in the original publication. The word should read as 'sensitized' throughout the article (including the title, abstract, introduction, results and discussion and conclusion).

The online version of the original article can be found under doi:10.1007/s10854-014-2000-5.

İ. Polat $(\bowtie)$

Department of Energy Systems Engineering, Faculty of

Technology, Karadeniz Technical University, 61830 Trabzon,

Turkey

e-mail: ismlpolat@yahoo.com

S. Yilmaz

Department of Materials Engineering, Faculty of Engineering and Natural Sciences, Adana Science and Technology

University, 01180 Adana, Turkey

E. Bacaksız · Y. Atasoy

Department of Physics, Faculty of Arts and Sciences, Karadeniz Technical University, 61080 Trabzon, Turkey

M. Tomakin

Department of Physics, Recep Tayyip Erdogan University,

Rize, Turkey 